\title{
Sedimentology and diagenesis of the Miocene Nutaysh Member of the Burqan Formation in the Midyan area (northwestern Saudi Arabia)
}

\author{
Khalid AL-RAMADAN ${ }^{1, *}$, Ahmet Umran DOGAN ${ }^{1,2}$ and Muhittin SENALP ${ }^{3}$ \\ 1 Department of Earth Sciences, King Fahd University of Petroleum and Minerals, Dhahran 3126, P.O. Box 1400, Saudi \\ Arabia \\ 2 Chemical and Biochemical Engineering Department and Center for Global and Regional Environmental Research \\ (CGRER), University of lowa, lowa City, lowa 52242, USA \\ 3 Field geology consultant, Turkey
}

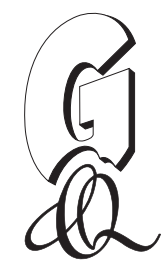

Al-ramadan K., Dogan A.U. and Senalp M. (2013) Sedimentology and diagenesis of the Miocene Nutaysh Member of the Burqan Formation in the Midyan area (northwestern Saudi Arabia). Geological Quarterly, 57 (1): 165-174, doi: 10.7306/gq.1081

Turbidite sandstones deposited in rift settings are currently among the main targets of hydrocarbon exploration. However, the impact of style of sedimentation, cyclicity and diagenesis on reservoir quality of such sandstones is relatively poorly explored in the literature. The sedimentology, stratigraphic architecture, and diagenetic alterations of deep marine sandstones of the Miocene Nutaysh Member of the Burqan Formation in the Midyan area (Saudi Arabia) are described based on number of measured sedimentologic sections, lithofacies identification in the field and laboratory studies. Three lithofacies types are here identified in the measured sections. These are from bottom to top: (1) "lithofacies A" consisting of massive to thickly-bedded, coarse-to-very coarse-grained sandstone and conglomerates; (2) "lithofacies B" consisting of well-bedded, coarse-to-medium-grained, well-sorted sandstone, and (3) "lithofacies C" consisting of thin-bedded, fine to very fine-grained, current-rippled sandstone, bioturbated shaley siltstone and marl. The main diagenetic processes in the sandstones include the formation of grain-coating smectite and rhombic dolomite. Small amounts of cements include the formation of authigenic kaolinite and calcite. The reservoir quality is anticipated to have been preserved under the transformation of smectite to deep burial illite, which is believed to prevent formation of quartz cements.

Key words: turbidite, lithofacies, diagenesis, Lower Miocene, Saudi Arabia.

\section{INTRODUCTION}

Deep-marine depositional systems are products of complex interactions between processes in the Earth's lithosphere, hydrosphere, and biosphere, and are one of the major remaining frontiers for natural resource exploration and development (Mutti et al., 2000). Relative changes in sea level, which occur primarily due to global eustasy and tectonic subsidence/uplift, represent major external controls on the sediment composition, budget, and architecture in deep-water depositional systems. Evaluation of the roles of these regional processes are of importance because they influence, among many things;

- spatial and temporal distribution of erosional and depositional systems both onshore and offshore (e.g., Wilgus et al., 1988; van Wagoner et al., 1990; Gawthorpe et al., 1994);

- architecture of deep-marine reservoir rocks.

\footnotetext{
* Corresponding author: e-mail: ramadank@kfupm.edu.sa Received: January 10, 2013; accepted: February 27, 2013; first published online: March 15, 2013
}

At a large scale, the primary reservoir properties of sandstones are controlled by several aspects of sediment and basin evolution, including sediment provenance, processes and settings of deposition, biological influences, and sea level and tectonic effects. These aspects of sediment evolution control the detrital mineralogy, grain size, sorting, spatial distribution, and sand/mud ratio. Post-depositional modification of original reservoir characteristics and quality occur during diagenesis and range from re-organization of the sediments by burrowing organisms, simple compaction and consolidation of the original grain framework during burial, multiple generations of cementation, grain and cement dissolution, matrix development, and grain alteration. These diagenetic processes are strongly controlled by the depth of burial and temperature, pore water chemistry, texture, organic matter content, and detrital composition of the siliciclastic sediments. Many of these key aspects of the evolution of reservoir quality are, in turn, linked to facies distribution and hence to the sediment source areas, depositional processes, and depositional environment.

The aims of this work are to unravel:

- sedimentological control on the Burqan Formation by describing and interpreting selected representative sections in the field; 
- parameters controlling the diagenetic evolution of deep-water turbiditic sandstones based on petrographic studies of deep marine Burqan Formation which is considered as a petroleum reservoir in the Midyan area, Saudi Arabia.

\section{REGIONAL EQUIVALENT OF THE BURQAN FORMATION}

Our literature review of the Miocene in the Saudi-Arabian part of the Gulf of Aqaba has revealed a very limited documentation (Fig. 1). More extensive work, however, has been carried out on the adjacent side of the gulf at the eastern coastline of the Sinai Peninsula - Egypt.

The formation of the Gulf of Aqaba is suggested to be linked to ancient fault systems of Upper Proterozoic to Lower Paleozoic (Patton et al., 1994). A continental crust had formed during the widespread Pan-African tectono-thermal event and is in contact with the Proterozoic Arabian-Nubian shield, which forms the basement of north-east African margin and western Saudi Arabia. The Proterozoic supercontinent was fragmented due to a 560 Ma rift event; a model that is consistent with events recorded in today's Gulf of Aqaba and corresponds well to published extension models of the area (Stern, 1985).

The first stratigraphic evidence of rifting is the deposition of Lower Miocene Nukhul Formation, Suez (Patton et al., 1994; Bosworth and McClay, 2001), with facies ranging from fluvial and shallow-marine clastics at the base, passing up into marls, anhydrites, and limestones at the top, which were deposited in an open marine environment (Fig. 2). In Jordan, the age-equivalent glauconitic sandstone, limestone, and sandstone deposits lie unconformably on top of Upper Eocene rocks in the Azraq-Faydat ad-Dahikiyah area (Bender, 1974). Different marls with a number of biostratigraphic markers, along with age-equivalent evaporite layers are found within the same stratigraphic succession.

The presence of a depositional hiatus on top of the Nukhul Formation marks the initiation of accelerated rifting, and separates the relatively shallow-marine deposits of the Nukhul Formation from the deep-marine deposits of the overlaying rift-climax Rudeis Formation (Patton et al., 1994). The hiatus may be related to accelerated tectonic subsidence at the end of the Nukhul Formation deposition. The bottom of this erosional boundary of the Lower Rudeis is marked by Globigerina marls, found adjacent to the eastern shoulder of the rift (Bosworth and McClay, 2001). However, the southern portion of the rift, show a marked coarsening in the grain size of the sandstone which indicates a significant sand supply from a local siliciclastic source within the terrenes of the rift basin. The presence of basement rock fragments was also documented in the Lower Rudeis Unit (Bosworth and McClay, 2001).

The top of Lower Rudeis is represented by an unconformity surface, based on different outcrop and subsurface data collected between the axial trough and rift shoulders along with biostratigraphic marker tests. The unconformity on top of the Lower Rudeis Formation is argued to be the result of the "mid-Clysmic" event, or regionally referred to as the "MidRudeis." The Upper Rudeis lays on top of the Mid-Rudeis boundary, and varies markedly from the Lower Rudeis based on facies analysis (Bosworth and McClay, 2001). The wide- spread uniformly distributed Globigerina marls of the Lower Rudeis are substituted by clastic-dominated sedimentary sequences, sub-marine alluvial fans, found along the shoulders of the rift, are deposited into the basin and margins, and shallow-marine carbonate-driven sediment gravity flows are deposited into the basin (Patton et al., 1994).

\section{GEOLOGICAL BACKGROUND OF BURQAN FORMATION}

The Miocene Burqan Formation is of late Early Miocene age and is subdivided into the sand dominated Nutaysh Member and the shale dominated Subayti Member (Fig. 2). These two members were deposited as submarine fans in the Midyan Basin (Hughes and Johnson, 2005). The Burqan Formation is stratigraphically located between the shallow marine carbonates of the Musayr Formation of the Tayran Group at the base, and the Kial Formation of the Magna Group (Fig. 2).

The Burqan Formation was named after the Auxerap/Tenneco exploration well-drilled in the offshore Burqan field. This formation is informally named the Globigerina Marls in unpublished (non Aramco) oil company reports. In the stratigraphy of Egypt, the Nutaysh Member corresponds to the Rudeis Formation, and the Subayti Member correlates with the Kareem Formation (Hughes and Johnson, 2005). The contact between the Musayr Formation and the Nutaysh Member of the Burqan Formation is strongly faulted. The very shallow marine carbonate rocks of the Musayr Formation are composed entirely of coral heads, large oyster shells and clams. The Musayr Formation is directly overlain by the sand-dominated Nutaysh Member.

The Nutaysh Member was deposited in a submarine environment and in many places of the Midyan Basin the well-bedded mid-fan facies contains large limestone blocks of the Musayr Formation. All these data show that the initial rifting caused the formation of a fault bounded basin (possibly pull-apart basin) on top of the Musayr Formation. The high areas, most possibly the horst blocks of the Musayr Formation, were severely eroded and provided carbonate detritus through the process of gravity sliding, slumping, and turbidity currents (Fig. 1). Therefore, the thickness and composition of the submarine lobes show significant variation in the Midyan Basin. These changes have a great impact on reservoir quality of the sandstone of the mid-fan region and also their overall exploration potential.

The Burqan Formation is a thick succession of deep-marine calcareous mudstones with thick sand interbeds. It is well-exposed in the Midyan region west of Jabal Rughama (Raghama) flanking the Maqna Massif and along the Gulf of Aqaba coast. Two members are recognized, the sand-dominated Nutaysh Member of the Burqan Formation (Clark, 1986) and the mudstone-dominated Subayti Member (Johnson et al., 1995). Rapid fault-controlled subsidence during the Early Miocene caused deposition of deep-marine, planktonic-foraminiferal mudstones and thick submarine fan sandstones of the Burqan Formation.

The Burqan Formation is well-exposed in the Midyan region. Turbidites, conglomerates, and sandstones of the Nutaysh Member characterize the basal part of the sequence, especially in the western part of Midyan. The presence of pebble and cobble conglomerates and pebbly sandstones amongst turbiditic sandstones suggests that a variety of sedimentary transport pro- 


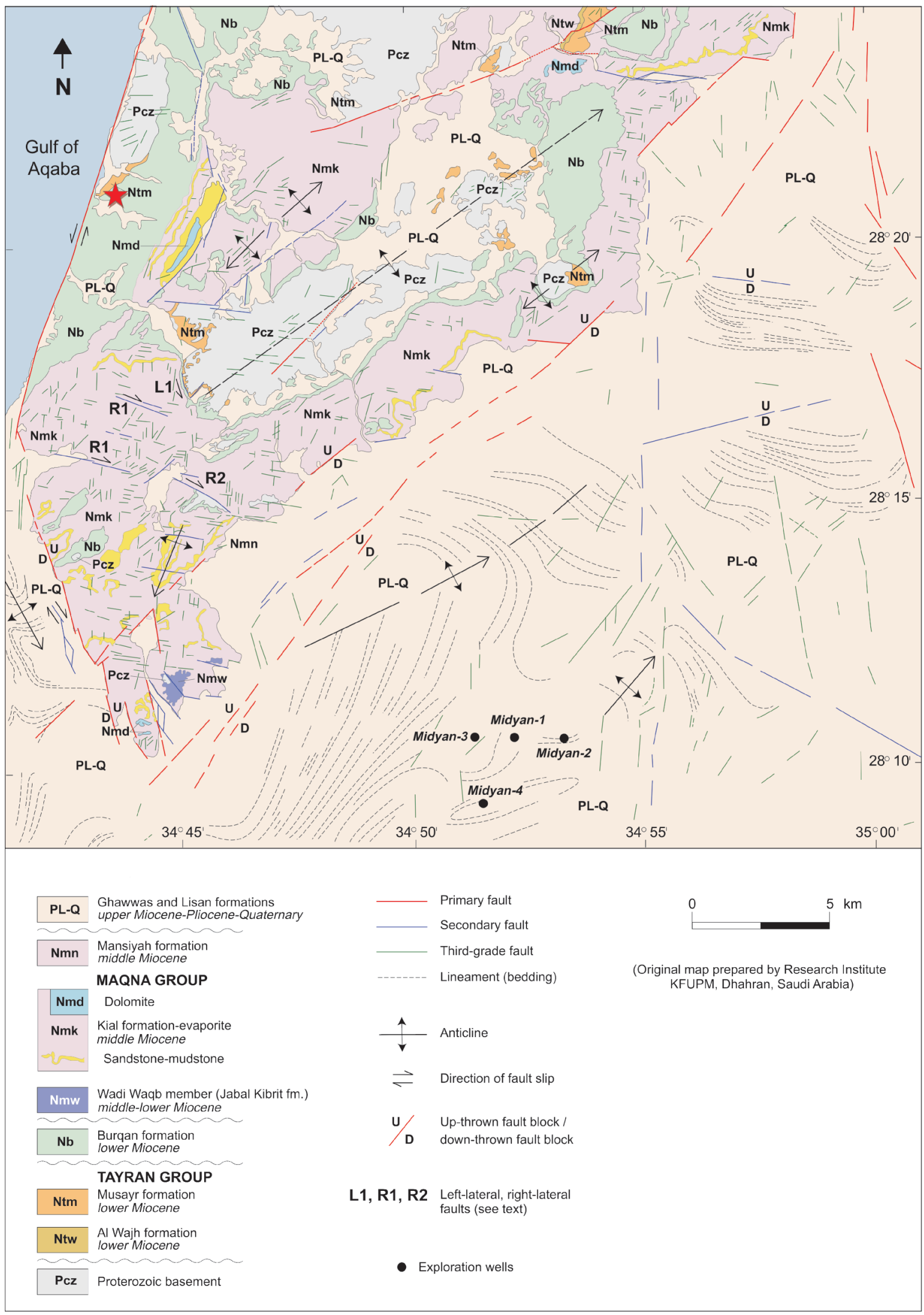

Fig. 1. Geological map of the study area (after Hughes et al., 1999)

Red star illustrates the location of the studied outcrops; the Nutaysh Member crops extensively in the western and northern portion of the Midyan Basin which is located south of the eastern margin of the Gulf of Aqaba 


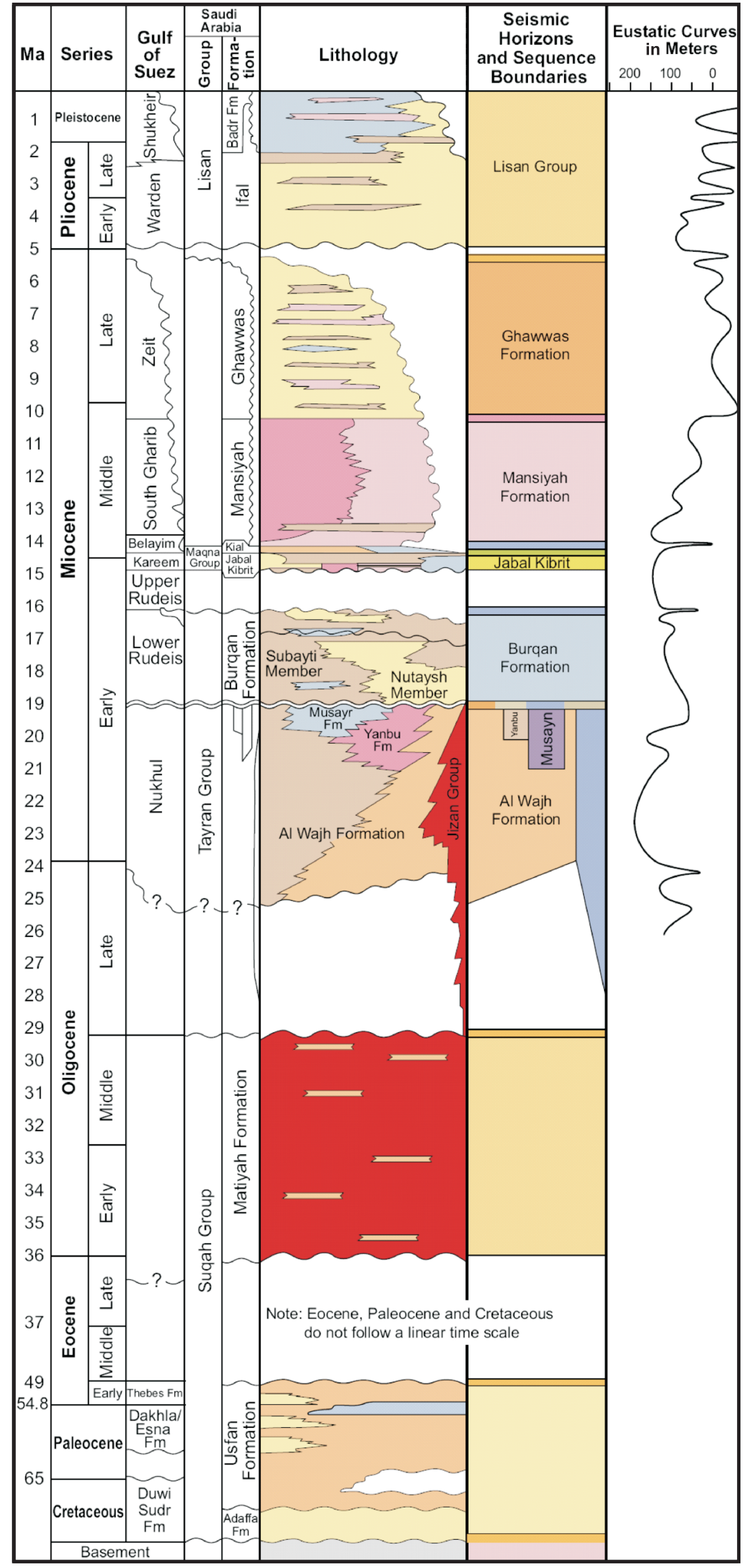

cesses may have been involved, at least in proximal locations, including inertial mass flows and "high density turbidites" that override conglomeratic traction carpets, as have been described in other syn-rift basins (e.g., Sohn et al., 1997; Abdullatif and Olagoke, 2010). In most of the exposures to the south-east, the upper part of the Burqan Formation is exposed and consists of calcareous mudstones of the Subayti Member. Clark (1986) estimated a total thickness of $400 \mathrm{~m}$ for the entire Burqan Formation. The calcareous mudstones are typically soft and characterized by ramifying anhydrite veinlets. The sandstone forms thick, massive, poorly consolidated beds as much as $4.5 \mathrm{~m}$ thick and is particularly well-exposed in the western area of the region in road-cuts along the "old Maqna road" (from $28^{\circ} 20^{\prime} 53.8^{\prime \prime} \mathrm{N}, 34^{\circ} 46^{\prime} 38.5^{\prime \prime} \mathrm{E}$ to $\left.28^{\circ} 20^{\prime} 04.6^{\prime \prime} \mathrm{N}, 34^{\circ} 45^{\prime} 26.5^{\prime \prime} \mathrm{E}\right)$.

An Early Miocene age (Late Aquitanian to Early Burdigalian) has been assigned to the Burqan Formation based on the presence of age-diagnostic planktonic foraminifera and calcareous nannofossils (Hughes and Johnson, 2005). These zones are based on the well-established extinction datums and include planktonic foraminifera.

The depositional environment of the Burqan Formation varied between structural elements and is likely to have varied in detail according to local position relative to active normal faults and fault relay zones. Analogous tectono-sedimentary relationships are well-documented in the Miocene of the Gulf of Suez Rift (Young et al., 2000; Jackson et al., 2005). Cyclical flooding and differential subsidence of fault blocks were responsible for variations in both clastic supply and water depth. The presence of certain benthic foraminifera, including Bathysiphon taurinensis, hispid Uvigerina spp. and Nodosaria spp., and the generally high diversity planktonic and deep marine benthic foraminiferal assemblages, indicate a predominantly bathyal depositional environment for the mud-dominated succession of the Nutaysh Member. Exposures of the Burqan Formation in the belt of northwestern outcrops in Midyan were interpreted as

Fig. 2. Generalized Red Sea stratigraphic column (after Hughes and Johnson, 2005)

The Nutaysh Member is part of the Burqan Formation which consists of two members: Nutaysh and Subayti; eustatic curve is after Haq et al. (1988) 
deep submarine-fan deposits (Ferguson and Senalp, 1993) with several sediment sources. In the north-west, proximal turbidites display decreasing grain size towards the south-east where they become distal fan turbidites. In the southeastern outcrop, however, flute marks on the base of beds exposed at the head of Wadi Waqb (28 $\left.12^{\prime} 58.4^{\prime \prime} \mathrm{N}, 34^{\circ} 44^{\prime} 40.6^{\prime \prime} \mathrm{E}\right)$ indicate transport of sediment from the south-east.

\section{METHODOLOGY}

Fieldwork in the Midyan area was carried out in the summer of 2011 to describe and analyse the facies distribution, measuring detailed stratigraphic sections, and to collect representative samples for sedimentology, petrography and geochemistry. A total of 52 samples were collected mainly from the two localities within the two lithofacies $A$ and $B$. Thin sections were prepared for all samples subsequent to vacuum impregnation with blue epoxy. Modal analyses of the 30 representative sandstone samples were performed by counting 300 points in each thin section. Scanning electron microscope (SEM) was used to study crystal habits and paragenetic relationships among diagenetic minerals in twenty representative samples. X-ray diffraction (XRD) analyses were performed on the fine fraction $(<20 \mu \mathrm{m})$ from twelve representative sandstone samples using a Rigaku Miniflex II X-ray diffractometers.

\section{RESULTS AND INTERPRETATION}

\section{SEDIMENTOLOGY AND STRATIGRAPHY}

The quartz sand-dominated fan deposits consist of massive to thickly-bedded very coarse to very fine-grained, graded bedded, friable to semi-friable sandstone, which would be a prime exploration target. On the other hand, the similar typical mid fan facies containing large amount of reworked carbonate debris of the Musayr Formation is well-cemented and tight. In the limestone blocks, deposited parallel to the stratification which show down the vertical migration of the hydrocarbon.

The first stratigraphic/sedimentologic section was measured on the east side of the Al Bad to Magana highway. In general, the lower part of the Nutaysh Member consists of 8.5 to $25 \mathrm{~m}$ thick fining upward sequences deposited as individual lobes of submarine fan environment. They are vertically and laterally stacked and are separated by green coloured well-bedded fine-grained basinal facies consisting of the calcareous shale, marl, siltstone, and very fine-grained wave rippled sediments were ramped the Subayti Member after the Subayti region of northwestern Midyan Basin (Ferguson and Senalp, 1993).

In the measured section (Fig. 3), the contact between the Nutaysh Member and the Musayr Formation is not well-exposed, however, this contact was exposed very well on both sides of the section. The thickness of the Nutaysh Member in this section is $435 \mathrm{~m}$. The stratigraphic sequence is well-preserved but severely faulted. The adverse effect of faulting was avoided by changing the course during the measurement. The lower $82 \mathrm{~m}$ of the measured section consist of five submarine fan lobes. They are vertically and laterally stacked, and separated by greenish-gray pelagic mudstones, marls and thin bedded sandstone. The lobe is around $25 \mathrm{~m}$ thick and shows a well-developed fining upward sequence. The 8.5-25 m thick fining upward sequences were subdivided into the "lithofacies
A" and "lithofacies B" (Fig. 4) and "lithofacies C". The five submarine fan lobes show almost the same vertical stacking pattern and consist of these three flithoacies with slight variations in their thickness.

Each lobe starts with a sharp erosional base overlain directly by "lithofacies A" (Fig. 5). This lithofacies forms more than $213 \mathrm{~m}$ of fining upward sequence and consists of regular accretions of 3.0 to $3.5 \mathrm{~m}$ thick graded bedded sandstone. The sandstone is very coarse-grained in the lower parts and coarse to medium grained in the upper parts.

Each homogeneous, massive, but graded bedded sandstone bed is separated by scoured surfaces. The scoured surfaces are covered by small pebbles derived from the Proterozoic Arabian-Nubian Shield. The "lithofacies A" is very poorly sorted in the lower $3.0 \mathrm{~m}$ interval but as the pebbles disappear upward, sorting gradually increase. The sandstones are friable or poorly consolidated and show good reservoir quality. The "lithofacies B" conformably overlies the "lithofacies A". It is generally light brown, coarse to medium-grained, horizontal planar-bedded and well-sorted sandstone. There are well-preserved burrows in the upper parts of this lithofacies.

The "lithofacies C" forms the uppermost part of the submarine fan lobe and is also present in the areas between the lobes. It includes well-defined, light gray to greenish-gray, very thinbedded, sandy marls, siltstone with very thin laminae of very fine-grained, wave-rippled, burrowed and bioturbated sandstone. There are cross-cutting secondary gypsum veins. The top of the unit is composed entirely of massive shale.

The thickness of each submarine fan lobe decreases upward from 15 to $25 \mathrm{~m}$. The fine-grained sandstone-, shale-, and mudstone-dominated "lithofacies C" gradually disappears upward and individual fan is closely packed and identification of the boundaries of each lobe become difficult to recognize. Thick lenses or even continuous beds of boulder conglomerate form a significant part of the stratigraphic section. This upper $353 \mathrm{~m}$ thick section still consist of short cycles of fining upward sequences that were deposited rapidly by the fragmentally occurring gravity slides, slumping, and other types of mass gravity flow. Their genetic relation with the underlying sand-dominated mid-fan facies suggests that this upper section was deposited in the inner fan and sub-marine canyon of the submarine fan system. The facies are very thick and a $353 \mathrm{~m}$ thick interval is measured in "lithofacies B" (Fig. 3); however, these two lithofacies are much thicker and coarser than the same facies described from the mid-fan parts. The base of this interval cuts deeply into the underling $10.5 \mathrm{~m}$ thick shale dominated "lithofacies C". The first interval is $55.5 \mathrm{~m}$ thick and consists of boulder conglomerate with a minor amount of very coarse grained sandstone. The boulders were derived from the Arabian-Nubian Shield.

There is evidence to suggest that the boulders were derived from the Musayr Carbonate Formation. The "lithofacies B" may be up to $25.5 \mathrm{~m}$ thick and consists of coarse to medium-grained massive sandstone. In some intervals, the "lithofacies A" and "lithofacies B" are closely associated and their separation becomes difficult. These intervals may be up to $45 \mathrm{~m}$ thick and consist of vertically stacked massive but mainly graded bedded sandstone intervals that contain thin lenses of conglomerate. Each graded sandstone bed ranges in grain size from very coarse to medium sand. The individual thickness of the boulder conglomerates range from 1.5 to $3.0 \mathrm{~m}$ (Fig. 5). The uppermost part of the section $(124 \mathrm{~m})$ consists of a regular alternation of the boulder conglomerate and coarse to medium-grained moderately sorted burrowed and bioturbated sandstone. There is $10 \mathrm{~m}$ thick covered interval between the top of the Nutaysh Member and the massive evaporite of the Kial Formation of the Magna Group. 


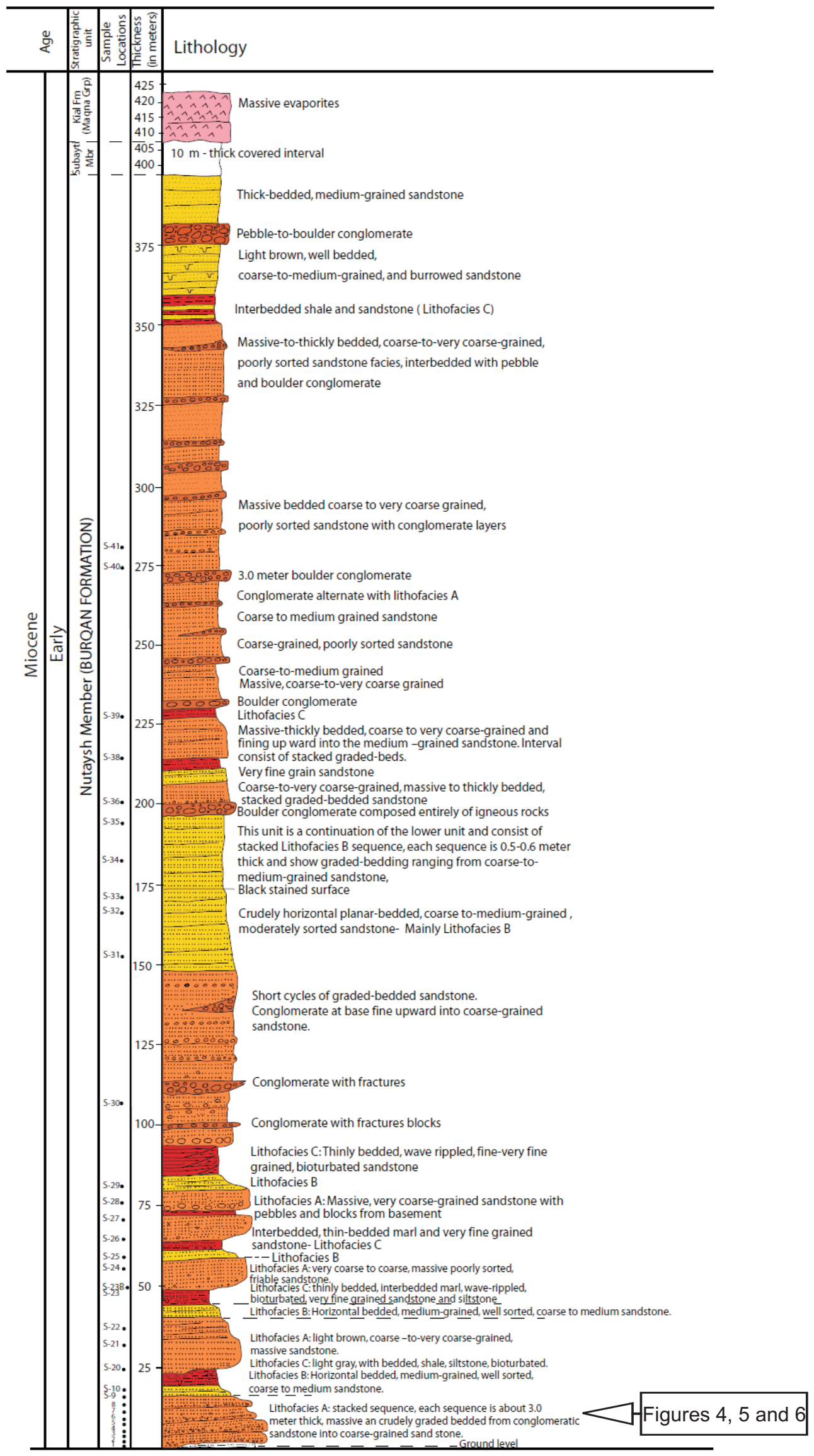

Fig. 3. Measured section of the Nutaysh Member in Midyan Peninsula (north-west Saudi Arabia) 


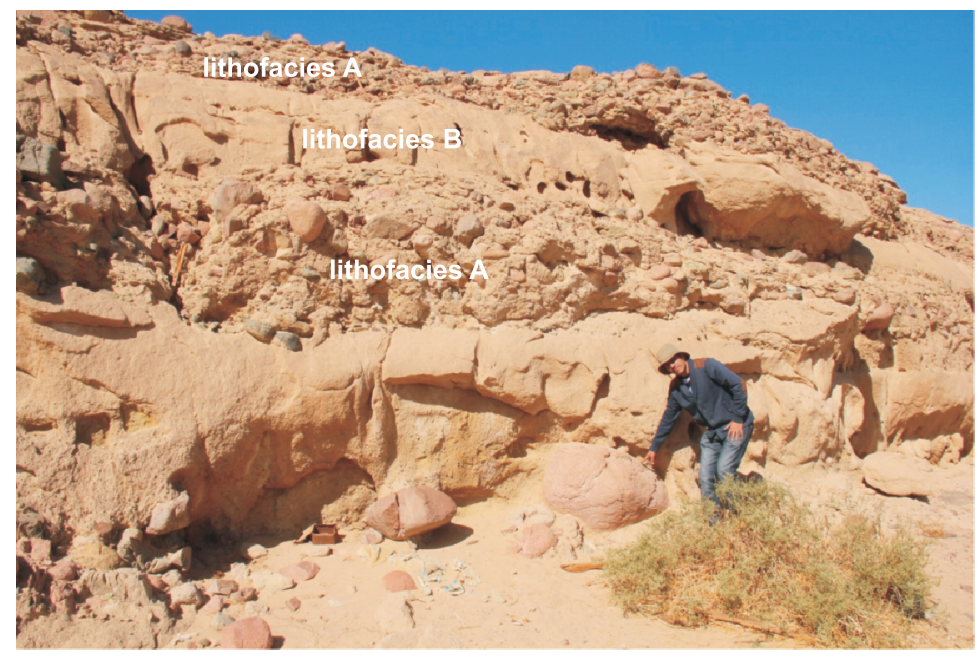

Fig. 4. Field photo showing lithofacies $A$ and $B$ of the Nutaysh Member (exposed in Maqna village, Midyan Basin)

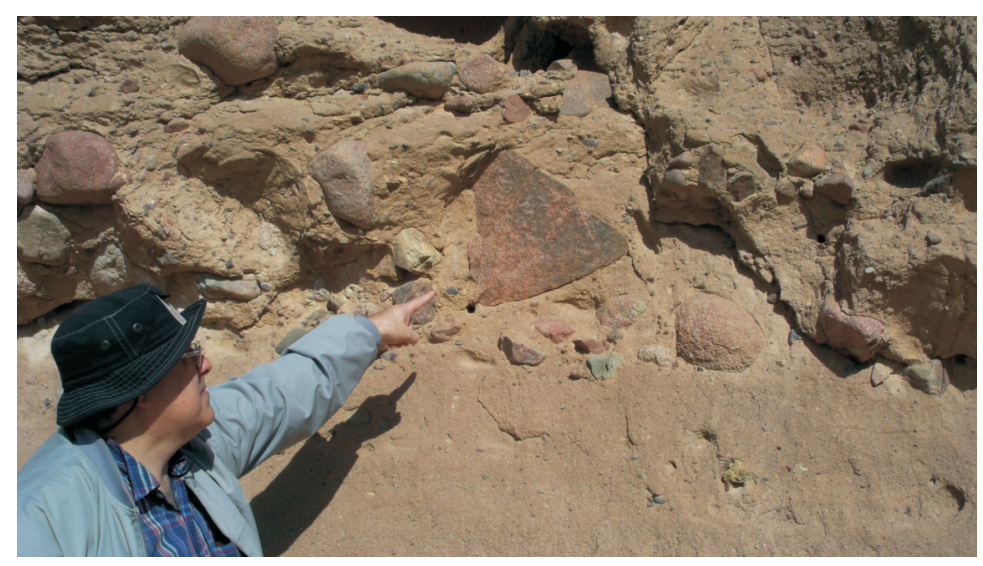

Fig. 5. Field photo showing close up view of the sharp base of "lithofacies A" that is characterized by big granitic boulders
The fining-upward sequences are still visible but they are not well developed in measured section 1. Each fining up parasequence is approximately $4 \mathrm{~m}$ thick. The lower part of the parasequence is conglomeratic, the middle portion is coarse to medium (rarely fine) grained sandstone which is overlain by thickly bedded (1.0 to $1.5 \mathrm{~m}$ ), very fine-grained and calcite cemented sandstones. The best part of the reservoir sandstone occurs in the middle parts of the fining upward sequences.

The depositional environment of the Burqan Formation is interpreted as a deep submarine fan and in the north-west of Midyan Basin, proximal turbidites display decreasing grain size toward the south-east where they become distal turbidites (Ferguson and Senalp, 1993). Sedimentary structures, indicating the sediment transport direction, are not common because of the coarse grain size of the sediments. During this study, a number of channel fill sandstones were observed, measured, and sampled. Their axes run mainly in a N53E direction and the flow direction is toward the SW.

\section{PETROGRAPHY AND DIAGENESIS}

The sandstones in "lithofacies A" are coarsegrained, poorly to moderately sorted whereas in "lithofacies B" they are fine to medium-grained, and moderately to well-sorted. Both lithofacies are subangular to subrounded, and arkosic. The average content of quartz is $77.1 \%$ (Table 1 ) where monocrystalline quartz dominates over polycrystalline quartz grains. Feldspar, which is abundant in all sandstones (av. 22.3\%; Fig. 6A), is dominated by plagioclase (av. 14.2\%) over K-feldspar (av. 8.1\%; Table 1). Some feldspars show partial dissolution (Fig. 6B). Mica constitutes low amounts and is mainly muscovite (av. 2.8\%; Fig. 6C). The lithic fragments (av. $0.3 \%$ ) are mainly low-grade metamorphics. Heavy minerals, which include primarily zircon, tourmaline, and rutile, occur in trace amounts (av. $0.4 \%)$.

The immature arkosic character of the Nutaysh

Table 1

The second measured stratigraphic/sedimentologic section of the Nutaysh Member is located in the other part of the Midyan Basin, less than $5 \mathrm{~km}$ west of Al Bad town. The measured section is only $35.5 \mathrm{~m}$ thick and represents the lowermost part of the section and the oldest lobe of the submarine fan (Fig. 4). Although the thickness of the lobe is very similar to that of the measured section 1, the composition and the reservoir quality of sandstones are very different. The good-quality reservoir sandstones were also individually measured and sampled for further studies.

In the second measured section, the contact between the Musayr and Burqan formations is well-exposed. The $10.5 \mathrm{~m}$ thick interval between the two formations is severely fractured and faulted. Three lithofacies, the Musayr limestone, the boulder conglomerate, and Nutaysh sandstone have been observed. This zone represents the commencement of the deep basin in which the thick deep submarine fan of the Burqan Formation was deposited. The formation of the deep basin was very rapid and took place soon after the deposition of the Musayr carbonates. The section contains a significant amount of limestone blocks derived from the Musayr Formation. Large portions of sandstones have also been cemented by calcite.

\begin{abstract}
Member containing fresh and angular feldspars sug-
\end{abstract}
Modal composition for detrital grains, diagenetic cements, and porosity from the sandstones studied

\begin{tabular}{|l|c|r|r|c|c|}
\hline \multirow{4}{*}{ Components } & \multicolumn{4}{|c|}{$[\%]$} \\
\cline { 2 - 6 } & Av. & Min. & Max. & SD \\
\hline \multirow{4}{*}{$\begin{array}{l}\text { Detrital } \\
\text { grains }\end{array}$} & quartz & 77.1 & 57 & 79 & 7.3 \\
\cline { 2 - 6 } & Klagioclase & 14.2 & 9 & 20 & 4.1 \\
\cline { 2 - 6 } & rock fragments & 0.3 & 0 & 2 & 8.2 \\
\cline { 2 - 6 } & mica & 2.8 & 1 & 10 & 2.4 \\
\cline { 2 - 6 } & heavy minerals & 0.4 & 0 & 1 & 8.4 \\
\hline \multirow{4}{*}{$\begin{array}{l}\text { Diagenetic } \\
\text { cements }\end{array}$} & dolomite & 2.7 & 1 & 15.7 & 4.3 \\
\cline { 2 - 6 } & smectite & 1.3 & 0 & 2 & 0.7 \\
\cline { 2 - 6 } & kaolinite & 1.1 & 0 & 2 & 1.6 \\
\cline { 2 - 6 } & calcite & 0.6 & 0 & 5 & 6.5 \\
\cline { 2 - 6 } & halite & 0.6 & 0 & 8 & 2.3 \\
\cline { 2 - 6 } & quartz overgrowth & 0.1 & 0 & 1 & 0.3 \\
\hline Porosity & total thin section & 21.5 & 15 & 30 & 5.5 \\
\hline
\end{tabular}


gests that during the initial stage of deposition, the Midyan Basin received sediments from an uplifted and less weathered source dominated by plagioclase and K-feldspar rich granites occurring to the north and northeast. Abundant plagioclase in the sandstones may indicate first-cycle derived, because plagioclase tends to be unstable during weathering. The low amount of feldspar alteration may be due to rapid erosion as a result of the high relief attained by large-scale block faulting in pre-Miocene and Early Miocene times and to conditions of extreme aridity.

Diagenetic minerals include dolomite, smectite, kaolinite, calcite, and quartz overgrowths. Dolomite is the predominant cement in the sandstones (av. 2.7\%; Table 1) and displays two textural habits including microcrystalline and rhombic $(\approx 50-100 \mu \mathrm{m})$ to poikilotopic (Fig. 7A). Dolomite is covered by and thus predates smectite. Smectite, which occurs as grain coating clay (av. 2.1\%), covers the dolomite and engulfed by quartz cement (Fig. 7B). The presence of smectite is in both lithofacies may reflect a high proportion of basic and ultrabasic debris compositions in the lower part of the unit, and relatively limited water circulation.

Several types of smectite may form as the weathering product of most igneous rocks such as acid (granite) and intermediate (diorite) igneous rocks (Christidis and Dunham, 1993, 1997). The weathering of plagioclase and alkali feldspars commonly leads to the formation of pseudomorphic dioctahedral smectite (e.g., montmorillonite; Aoudjit et al., 1995). Conversely, the weathering of Fe-Mg rich minerals (i.e., biotite or pyroxene) results in them being pseudomorphed by trioctahedral smectite such as saponite (Hill et al., 2000).

Kaolinite occurs as grain replacive mica and feldspar (trace to $1.1 \%$; Fig. 7C). The low amount of kaolinite in both lithofacies may be attributed to the arid to semi arid palaeoclimatic conditions (Brański, 2010), which is supported by the presence of high amount of smectite (av. 2.1\%). Calcite, which occurs as concretions, has a poikilotopic texture (Fig. 8A).

Turbiditic sandstones forming in the rift basins are rich in feldspar, and thus mechanically stable but chemically fairly unstable, and have moderate to poor potential to form good reservoirs. Porosity in deep-water turbiditic sandstones from passive margin settings consists of variable amounts of intergranular and intragranular micropores $(<10 \mu \mathrm{m})$. Intragranular pores are commonly formed by partial dissolution of detrital feldspar and mica (Fig. 8B). Significant amounts of microporosity, which induces high water saturation in the reservoir sandstones, occur within smectite and kaolinite crystals that have replaced feldspars and micas.

Due to the lack of subsurface samples, we can speculate on the reservoir quality based on the literature. The presence of a high amount of grain-coating smectite in the studied sandstone is believed to be converted into illite under the availability of potassium. The abundant K-feldspar (av. 8.1\%) is likely to release $\mathrm{K}^{+}$via replacement at deep burial (Worden and Morad, 2003). Grain-coating illite is believed to preserve porosity at greater depth (Ehrenberg, 1993).

\section{CONCLUSIONS}

Two representative stratigraphic sections of the Nutaysh Member were measured. The first section is $435 \mathrm{~m}$ thick and located on the east side of the Al Bad to Magana highway. This section is composed of a fining upward sequence of sandstones, indicating a submarine fan environment. Five individual submarine fan lobes are observed in the lower $82 \mathrm{~m}$ of the sec-
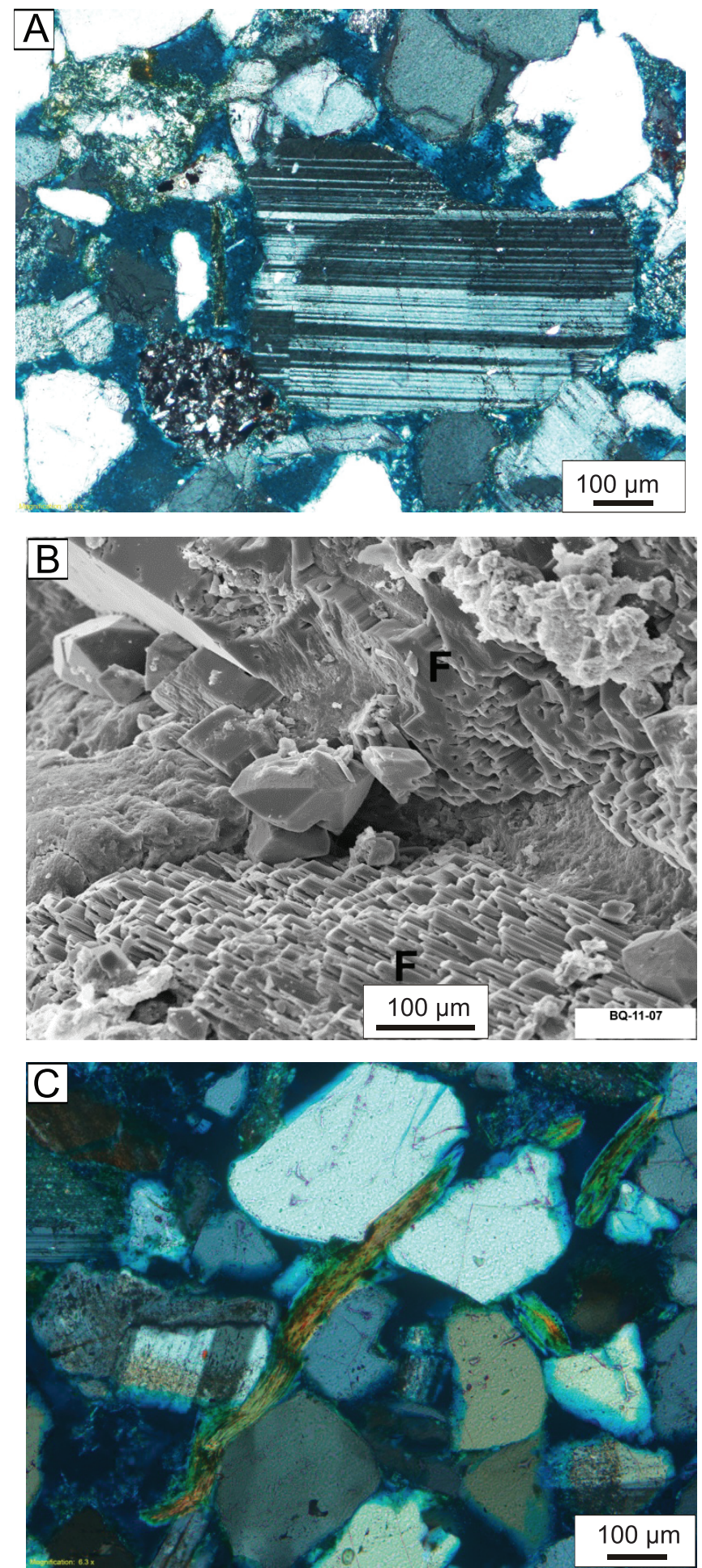

Fig. 6A - optical micrograph (crossed polars) showing K-feldspar, plagioclase grains in "lithofacies A"; B - SEM micrograph showing authigenic quartz precipitating between feldspathic framework grains which show partial dissolution (F); C - optical micrograph (crossed polars) showing mica grains in "lithofacies A"

tion. The fining upward sequences were subdivided into three facies as facies: A, B, C. The stratigraphic sequence is well-preserved, but, severely faulted.

The second measured stratigraphic section is only $35.5 \mathrm{~m}$ thick and is located in the other part of the Midyan Basin, $5 \mathrm{~km}$ 

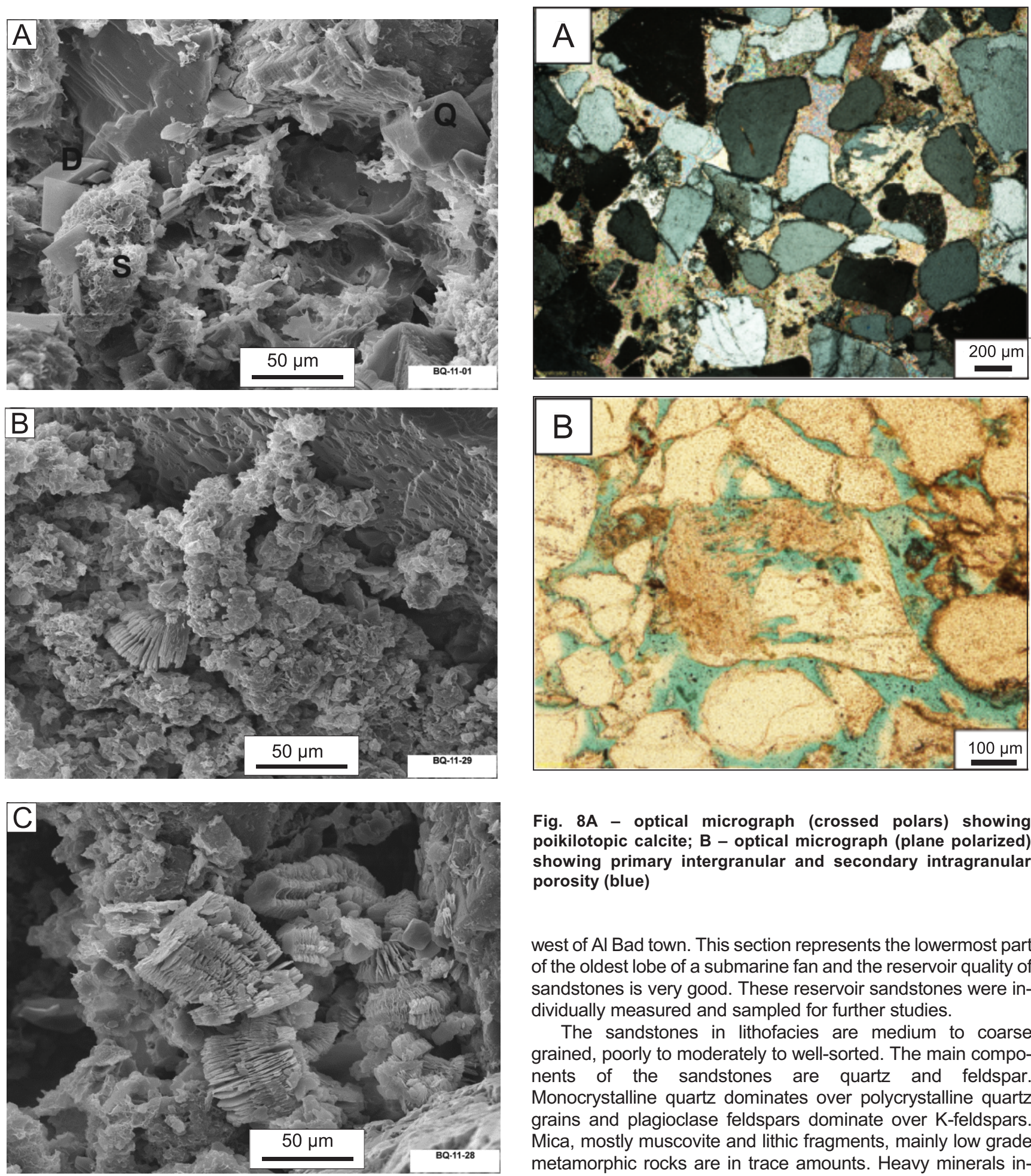

Fig. 8A - optical micrograph (crossed polars) showing poikilotopic calcite; B - optical micrograph (plane polarized) showing primary intergranular and secondary intragranular porosity (blue)

west of Al Bad town. This section represents the lowermost part of the oldest lobe of a submarine fan and the reservoir quality of sandstones is very good. These reservoir sandstones were individually measured and sampled for further studies.

The sandstones in lithofacies are medium to coarse grained, poorly to moderately to well-sorted. The main components of the sandstones are quartz and feldspar. Monocrystalline quartz dominates over polycrystalline quartz grains and plagioclase feldspars dominate over K-feldspars. Mica, mostly muscovite and lithic fragments, mainly low grade metamorphic rocks are in trace amounts. Heavy minerals include zircon, rutile, and tourmaline are also in trace amounts.

Diagenetic minerals observed in the pore system include

Fig. 7. SEM micrographs showing: A - authigenic dolomite precipitated as euhedral rhombs (D), authigenic quartz cement (Q) and authigenic smectite (S); note the webby clays as pore bridging material which inhibits permeability; B - pore filling smectite followed by kaolinite; C - grain replacive kaolinite that is characterized by high microporosity authigenic clay minerals (smectite, kaolinite), carbonates (dolomite, calcite), and minor quartz. Kaolinite observed in pores is well-developed and vermiform, however, in low amounts possibly due to the arid and semi-arid climate conditions. On the other hand, smectite is more abundant and coats the grains. Dolomite creates microcrystalline and rhombic forms. Calcite cement shows poikilotopic texture. Minor amounts of quartz are also observed. 
Significant amounts of microporosity are observed as intergranular and intragranular micropores. However, due to the lack of subsurface samples, we cannot speculate on the conditions in the subsurface. The presence of high amount of grain-coating smectite type clay is believed to convert to illite at depth, which may preserve the porosity of the sandstone units, making them an economically better target. Further study, specifically for the subsurface is warranted, in order to provide clearer picture of the reservoir quality of the already promising the Burqan Formation.
Acknowledgements. The authors would like to acknowledge the support and help they have received from the King Fahd University of Petroleum and Minerals by providing funds through their Fast Track research program (FT101006). Thanks also are extended to Mr. M. Aqel for his assistance in the field. We thank the journal reviewers A. Kozłowska and N. Oszczypko for their comments.

\section{REFERENCES}

Abdullatif O., Olagoke S. (2010) The Early Miocene deep marine turbidites of Burqan Formation: facies, characteristics, and reservoir quality, Midyan region, Saudi Arabia. Geophysical Research Abstracts, 12, EGU2010-8093.

Aoudjit H., Robert M., Elsass F., Curmi P. (1995) Detailed study of smectite genesis in granitic saprolites by analytical electron microsopy. Clays and Clay Minerals, 30: 135-147.

Bender F. (1974) Geology of Jordan. Gebrueder Borntraeger, Berlin.

Bosworth W., McClay K. (2001) Structural and stratigraphic evolution of the Gulf of Suez rift, Egypt: a synthesis. Mémoires du Muséum d'Histoire Naturelle, 186: 567-606.

Brański P. (2010) Kaolinite peaks in early Toarcian profiles from the Polish Basin - an inferred record of global warming. Geological Quarterly, 54 (1): 15-24.

Christidis G., Dunham A.C. (1993) Compositional variations in smectites. Part 1: alteration of intermediate volcanic rocks. A case study from Milos Island, Greece. Clays and Clay Minerals, 28: $255-273$.

Christidis G., Dunham A.C. (1997) Compositional variations in smectites. Part 2: alteration of acidic precursors, a case study from Milos Island, Greece. Clays and Clay Minerals, 32: 253-270.

Clark M.D. (1986) Explanatory notes to the geologic map of the Al Bad'Quadrangle, sheet 28A, Kingdom of Saudi Arabia. Saudi Arabian Deputy Ministry for Mineral Resources Geoscience Map Series GM-81A, C, scale 1:250 000 (unpublished).

Ehrenberg S.N. (1993) Preservation of anomalously high porosity in deeply buried sandstones by grain-coating chlorite: examples from the Norwegian continental shelf. AAPG Bulletin, 77: 1260-1286.

Ferguson G.S., Senalp M. (1993) Sedimentology of the Nutaysh Formation (Burqan Group), and other stratigraphic insights; evidence from a field trip to the Midyan Area. Saudi Aramco Miscellaneous Report, 1001 (unpublished).

Gawthorpe R.L., Fraser A., Collier R.E.Li. (1994) Sequence stratigraphy in active extensional basins: implications for the interpretation of ancient basin fills. Marine and Petroleum Geology, 11: 642-658.

Haq B.U., Hardenbol J., Vail P.R. (1988) Mesozoic and Cenozoic chronostratigraphy and eustatic cycles. SEPM Special Publication, 42: 71-108.

Hill I., Worden R.H., Meighan I.G. (2000) Geochemical evolution of a palaeolaterite: the interbasaltic formation, Northern Ireland. Chemical Geology, 166: 65-84.
Hughes G.W., Johnson R.S. (2005) Lithostratigraphy of the Red Sea region. GeoArabia, 10: 49-126.

Hughes G.W., Perincek D., Grainger D.J., Abu-Bshait A., Jarad A. (1999) Lithostratigraphy and depositional history of part of the Midyan region, northwestern Saudi Arabia. GeoArabia, 4: 503-542.

Jackson C.A.L., Gawthorpe R.L., Carr I.D., Sharp I.R. (2005) Normal faulting as a control on the stratigraphic development of shallow marine syn-rift sequences: the Nukhul and Lower Rudeis Formations, Hammam Faraun fault block, Suez Rift, Egypt. Sedimentology, 52: 313-338.

Johnson R.S., Rodgers D., Savage G.R. (1995) Red Sea exploration program, Saudi Arabia coastal plain. Saudi Aramco Miscellaneous Report, 1029 (unpublished).

Mutti E., Tinterri R., Remacha E., Mavilla N., Angella S., Fava L. (2000) An introduction to the analysis of ancient turbidite basins from an outcrop perspective: Tulsa, Oklahoma. AAPG Continuing Education Course Note Series, 39.

Patton T.L., Moustafa A.R., Nelson R.A., Abdine S.A. (1994) Tectonic evolution and stratigraphic setting of the Suez rift. AAPG Special Publication, 59: 7-55.

Sohn Y.K., Kim. S.B., Hwang I.G., Bahk J.J., Choe M.Y., Chough S.K. (1997) Characteristics and depositional processes of large-scale gravelly Gilbert type foresets in the Miocene Doumsan fan delta, Pohang basin, SE Korea. Journal of Sedimentary Research, 67: 130-141.

Stern R.J. (1985) The Najd Fault System, Saudi Arabia and Egypt: a late Precambrian rift related transform system? Tectonophysics, 4 (5): 497-511.

Van Wagoner J.C., Mitchum R.M., Campion K.M., Rahmanian V.D. (1990) Siliciclastic sequence stratigraphy in well logs, cores, and outcrops. AAPG Methods in Exploration Series, 7.

Wilgus C.K., Hastings B.S., Kendall C.G., Posamentier H.W., Ross A., van Wagoner J.C. (1988) Sea level changes: an integrated approach. SEPM Special Publication, 42.

Worden R.H., Morad S. (2003) Clay minerals in sandstones: controls on formation distribution and evolution. IAS Special Publications, 34: 3-41.

Young M.J., Gawthorpe R.L., Sharp I.R. (2000) Sedimentology and sequence stratigraphy of a transfer zone coarse-grained fan delta, Miocene Suez Rift, Egypt. Sedimentology, 47: 1081-1104. 